\title{
In-vitro Antiproliferative Activity Study of 2, 4, 5-Triphenyl-1H-imidazole Derivatives
}

\section{Abstract}

Various substituted 2, 4, 5-triphenyl- $1 \mathrm{H}$-imidazole derivatives were synthesized and evaluated for in vitro antiproliferative activity against human non-small cell lung carcinoma-A549 cell lines by MTT assay method. Compound 2-iodo-6methoxy-4-(4, 5-diphenyl-1H-imidazol-2-yl) phenol (6f) $\left(\mathrm{IC}_{50}: 15 \mu \mathrm{M}\right)$ was found to be most promising which inhibits the growth of cancer cells $(90.33 \%$ of total population).

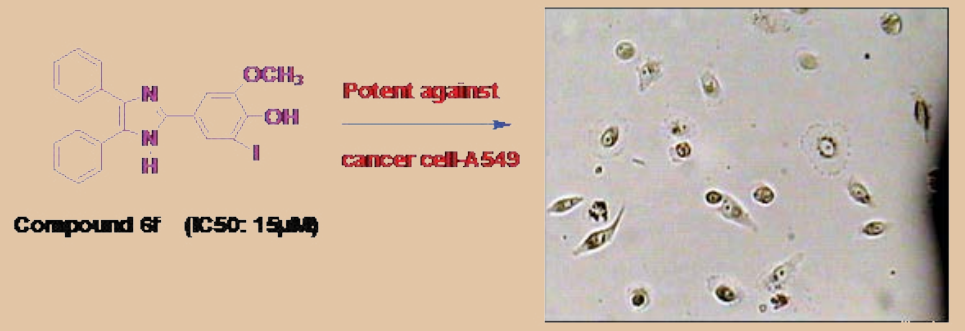

In vitro antiproliferative activity study of 2, 4, 5-triphenyl-1H-imidazole derivatives

Keywords: Antiproliferative activity; Imidazoles; Melanoma cells

Received: August 07, 2017; Accepted: September 05, 2017; Published: September 12, 2017

\section{Introduction}

Heterocyclic compounds containing nitrogen atom in their structure showed pharmacological interest and belongs to the imidazole family. Substituted 2, 4, 5-triaryl- $1 H$-imidazoles have been gained the remarkable significance due to their wide range of biological activities. Imidazole ring is one of the most important structures found in many natural products, and in pharmacologically active compounds such as anti-ulcerative agent cimetidine, the proton pump inhibitor omeprazole and the benzodiazepine antagonist flumazenil. They reduced the platelet aggregation in numerous animal species and humans.

Imidazoles are playing a vital role in biochemical processes [1]. Imidazole compounds have shown estrogen receptor and cytotoxic inhibitors of the cyclooxygenase [2], antifungal [3], antihelmitic [4], analgesic [5], fungicidal [6], anti-inflammatory [7], antithrombotic activities [8]. Substituted imidazole possesses potentially novel therapeutic activities [9], and controlled processes [10]. In addition to these, they are also known for pesticidal and herbicidal activity. Imidazoles are the

\author{
Satish A Dake ${ }^{1}$, \\ Kiran R Kharat², \\ Ashok R Yadav ${ }^{1}$, \\ Pravin S Kendrekar ${ }^{3}$ and \\ Rajendra P Pawar ${ }^{1^{*}}$
}

1 Department of Chemistry, Deogiri College, Aurangabad, Maharashtra, India

2 Department of Biotechnology, Deogiri College, Maharashtra, India

3 Department of Health Sciences, Central University of Technology, Bloemfontein 9300, Free State, South Africa

* Corresponding author:
Rajendra P Pawar

Đ rppawar@yahoo.com

Department of Chemistry, Deogiri College, Station Road, Aurangabad-431 005, Maharashtra, India.

Tel: 02402367333

Citation: Dake SA, Kharat KR, Yadav AR, Kendrekar PS, Pawar RP (2017) In-vitro Antiproliferative Activity Study of 2, 4, 5-Triphenyl-1H-imidazole Derivatives. J Org Inorg Chem Vol. 3 No. 2: 5.

core structures of various biological systems such as histidine, histamine and biotin which are active components in several drug molecules (e.g., Losartan, Olmesartan and Eprosartan) peptides.

Nowadays, scientists are trying to develop new synthetic methodology for the use of chemicals that reduce risk to human and animal species. Some methods are reported for the preparation of trisubstituted imidazoles from pharmacological and synthetic point of view.

In continuation of our previous research work in the development of synthetic methodologies such as, sulfated tin oxide: a reusable and highly efficient heterogeneous catalyst for the synthesis of 2,4,5-triaryl- $1 H$-imidazole derivatives [11], and the bioactivity and synthesis of substituted benzimidazole motifs [12]. An 
efficient noncatalytic protocol for the synthesis of trisubstituted imidazole in polyethylene glycol using microwaves was studied [13]. An efficient synthesis of 2,4,5-triaryl substituted imidazoles under solvent free conditions at room temperature was reported [14]. Microwave-assisted facile synthesis of 2-substituted 2-imidazolines has been reported [15]. Certain synthetic methodology has been investigated including, an efficient synthesis of 2,4,5-triaryl-1h-imidazole derivatives catalyzed by boric acid in aqueous media under ultrasound-irradiation [16]. Same type of biological screening is done by our researchers such as; Ionic liquid promoted synthesis, antibacterial and in vitro antiproliferative activity of novel $\alpha$-aminophosphonate derivatives [17] induction of mitochondria mediated apoptosis in human breast cancer cells ( $t-47 d$ ) by Annona Reticulata I. leaves methanolic extracts [18].

Our previous reported research works explain only the synthetic methods of imidazoles. But, in this work, we evaluated antiproliferative activity of the synthesized substituted 2, 4, 5 -triaryl- $1 \mathrm{H}$-imidazoles. The viability of human non-small cell lung carcinoma-A549 cells have been analyzed by MTT assay method.

\section{Materials and Methods}

\section{Sample preparation}

Each compound was dissolved in dimethyl sulfoxide (DMSO) to get a final concentration of $10 \mathrm{mg} / \mathrm{ml}$ and sterilized by 0.2 -micron membrane filtration.

\section{Cell culture conditions}

Human non-small cell lung carcinoma A549 cells were maintained in RPMI 1640 (Life technologies Inc. USA) containing 10\% heat-inactivated FBS (Life technologies Inc. USA) and $50 \mu \mathrm{g} /$ $\mathrm{mL}$ Gentamicin (Himedia, India). The cells were grown at $37^{\circ} \mathrm{C}$ temperature in incubator supplied with $5 \% \mathrm{CO}_{2}$. When grow to $65 \%-80 \%$ confluency, the cells were trypsinized with $0.25 \%$ TPVG solution (Himedia, India), counted and aliquot at the desired density for growth assays. All the experiments were done using $48 \mathrm{~h}$ grown cells.

\section{Determination of cell viability and the MIC}

The effect of compounds on viability of A549 cells was determined by MTT cell proliferation assay. The cells were plated at $\sim 1 \times 10^{3}$ cells in each well of 96 well plates in $100 \mu \mathrm{L} \mathrm{RPMI}$ 1640 medium. 0 to $20 \mu \mathrm{M}$ of compound was added to each well. Each concentration of imidazole compounds was repeated in 8 wells. Cell viability was determined after $24 \mathrm{~h}$ incubation in $\mathrm{CO}_{2}$ incubator at $37^{\circ} \mathrm{C}$. MTT (5 mg/mL in PBS) was added to each well and incubated for $4 \mathrm{~h}$. The absorbance was recorded at 490 $\mathrm{nm}$ for all the 96 well plates Multiscan Ascent (Thermo Inc). The inhibitory effect of imidazole compounds on cell growth was assessed as percent cell viability. Cells without treatment were considered as more than $80 \%$ viable. The $\%$ viability of carcinoma cell was analyzed in presence of substituted 2, 4, 5-triphenyl-1Himidazoles (Graph 1).

\section{Time dependence and sensitivity assay}

The cells were seeded at 10000 cells/well in 12 -well plates. A fixed concentration of $10 \mu \mathrm{M}$ was added to each well and incubated for $48 \mathrm{~h}$. After an interval of $6 \mathrm{~h}$, the \% survival of each well was calculated. Time and concentration dependent analysis was done at $20 \mu \mathrm{M}$ concentration of novel derivative of imidazoles (Graph 2).

\section{Results and Discussion}

In this study, a series of novel substituted 2,4,5-triphenyl- $1 \mathrm{H}$ imidazole derivatives $(1 \mathrm{a}, 2 \mathrm{~b}, 3 \mathrm{c}, 4 \mathrm{~d}, 8 \mathrm{~h}, 6 \mathrm{f}, 7 \mathrm{~g}, 9 \mathrm{i}, 11 \mathrm{j}, 12 \mathrm{k}, 13 \mathrm{l}$, $18 \mathrm{~m}, 19 \mathrm{n}, 21 \mathrm{o})$ have been evaluated for in vitro antiproliferative activity against human A549 cancer cell lines.

We have examined the effect of various 2,4,5-triphenyl- $1 H$ imidazole compounds on the viability of cultured carcinoma cells which showed promising antiproliferative activity against A549 cancer cell lines by MTT method. Melanoma cells were incubated with $20 \mu \mathrm{M} \mathrm{2,} \mathrm{4,} \mathrm{5-triphenyl-} 1 \mathrm{H}$-imidazole derivatives for 24 hours and their viability was assessed. The cell viability was assessed by MTT assay after $24 \mathrm{~h}$ of growth at $37^{\circ} \mathrm{C}$. The $\%$ viability of carcinoma cell analyzed in presence of substituted 2 , 4, 5-triphenyl- $1 \mathrm{H}$-imidazoles. Time and concentration dependent analysis was done at $20 \mu \mathrm{M}$ concentration of the novel derivative of imidazoles.

The compound 2-iodo-6-methoxy-4-(4,5-diphenyl-1H-imidazol$2-\mathrm{yl})$ phenol (6f) showed predominant growth inhibition of the melanoma cells $90.33 \%$ due to the presence of heteroatom nitrogen, phenolic $-\mathrm{OH}, \quad-\mathrm{I}$ and $-\mathrm{OCH}_{3}$ groups.

We have not only explored promising antiproliferative activity of $6 f$ compounds but also, other imidazole compounds exhibited potent in vitro antiproliferative activity. Newly substituted 2, 4, 5-triphenyl- $1 \mathrm{H}$-imidazole derivatives are $(7 \mathrm{~g}),(9 \mathrm{i}),(12 \mathrm{k}),(13 \mathrm{I})$, (18m), (19n) and (210) as compared to the standard (control C4p) have been showed promising lung carcinoma-A549 cell growth inhibition activity (Table 1).

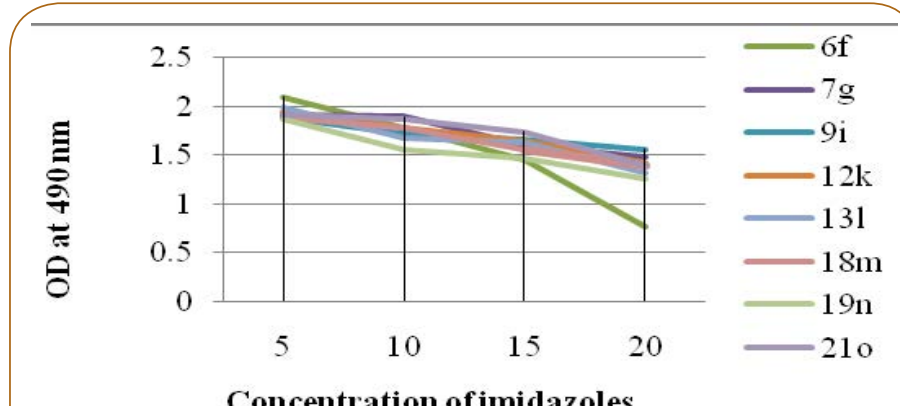

Graph 1 Effect of imidazole derivatives on cancer cell line A549. The MTT assay was performed on A549 cell.

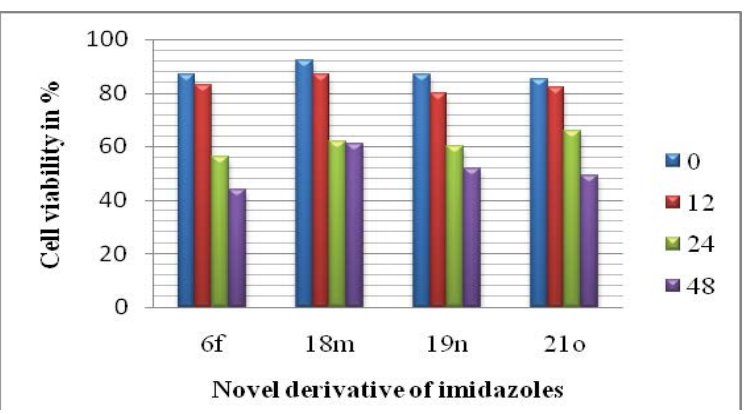

Graph 2 Time and dose dependent assay of imidazole derivatives on human lung carcinoma cell. 
Table 1 Antiproliferative activity of 2,4,5-triphenyl-1H-imidazole derivatives against melanoma cell A549.

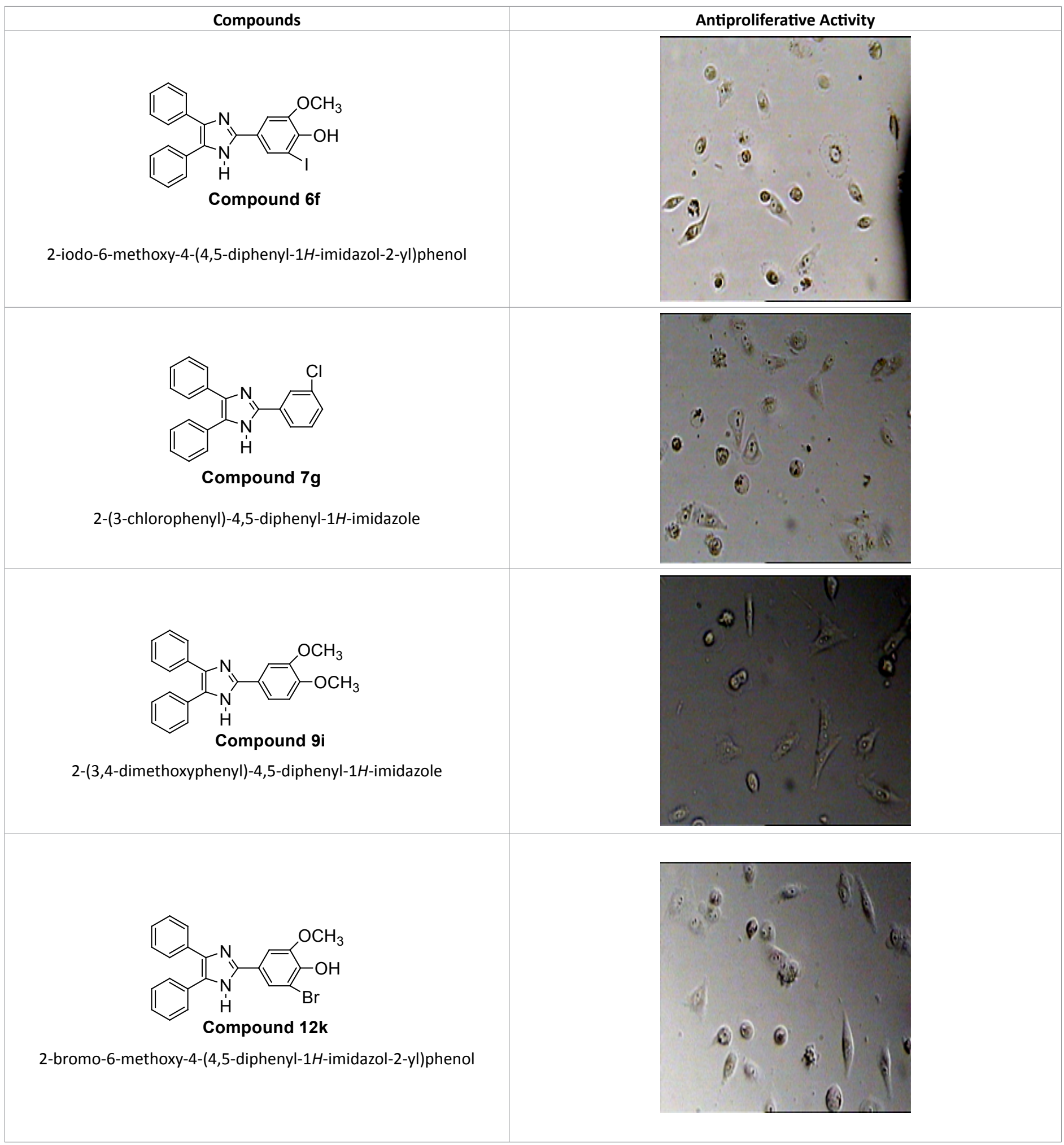




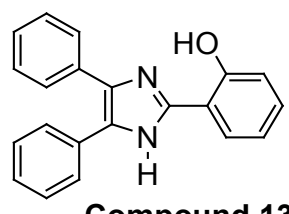

Compound 13I

2-(4,5-diphenyl-1H-imidazol-2-yl)phenol

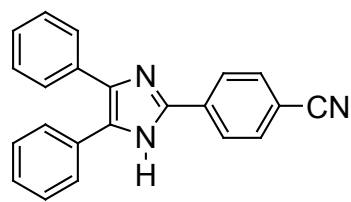

Compound $18 \mathrm{~m}$

4-(4,5-diphenyl-1H-imidazol-2-yl)benzonitrile<smiles>Cc1nc(-c2nc(-c3ccccc3)c(-c3ccccc3)[nH]2)c[nH]1</smiles>

Compound 19n

2-(2-methyl-1H-imidazol-4-yl)-4,5-diphenyl-1H-imidazole

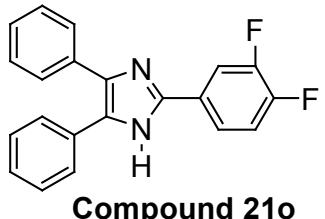

Compound 210

2-(3,4-difluorophenyl)-4,5-diphenyl-1H-imidazole
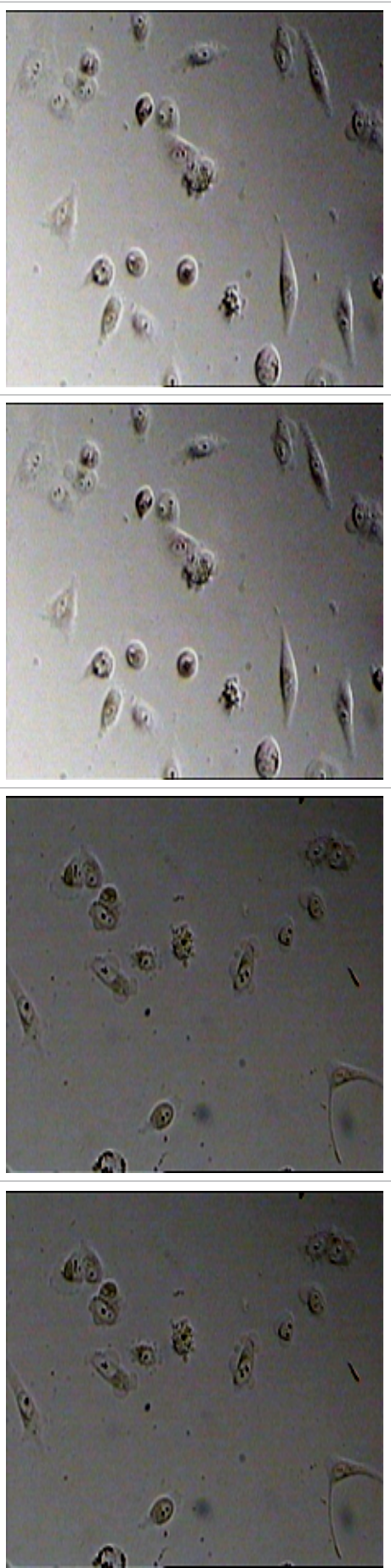

Control C4p

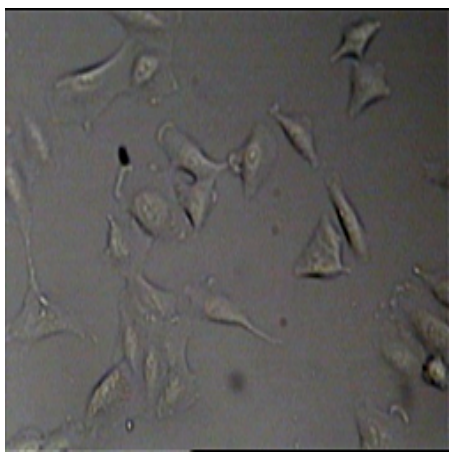


Among them, compounds 2-methoxy-4-(4,5-diphenyl-1Himidazol-2-yl) phenol (4d) and 2-(3-nitrophenyl)-4,5-diphenyl$1 \mathrm{H}$-imidazole (11j) showed moderate activity $48.18 \%$ and $45.16 \%$ respectively which is less than $50 \%$ inhibition of cancer cell line as compared to the standard (control). Compound 2-(4-chlorophenyl)-4,5-diphenyl-1H-imidazole (8h) showed very less antiproliferation of cells i.e., $29 \%$, while compounds 2,4,5-triphenyl- $1 \mathrm{H}$-imidazole (1a), 4-(4,5-diphenyl- $1 \mathrm{H}$-imidazol2-yl) phenol (2b) and 2-(4-methoxy phenyl)-4,5-diphenyl-1Himidazole (3c) does not showed any inhibition activity against cancer cell line. Compounds $6 \mathrm{f}, 7 \mathrm{~g}, 9 \mathrm{i}, 12 \mathrm{k}, 13 \mathrm{l}, 18 \mathrm{~m}, 19 \mathrm{n}$ and 210 were found to be promising antiproliferative against melanoma cancer cell lines.

\section{Conclusion}

In the present study, some new imidazoles were evaluated for in vitro antiproliferative activity against human non-small cell lung carcinoma-A549 cell lines by MTT assay method. Tested compounds $6 \mathrm{f}, 7 \mathrm{~g}, 9 \mathrm{i}, 12 \mathrm{k}, 13 \mathrm{l}, 18 \mathrm{~m}, 19 \mathrm{n}$ and 210 showed significant growth inhibitory effects. Compound 2-iodo-6methoxy-4-(4,5-diphenyl- $1 H$-imidazol-2-yl) phenol (6f) (IC $: 15$ $\mu \mathrm{M})$ was found to be most promising, inhibit growth of cancer cells $(90.33 \%$ of total population).

This study provides innovative idea about in vitro antiproliferative activity of 2, 4, 5-triphenyl- $\mathrm{H}$-imidazole derivatives and provide a valuable information for further development of more potent anticancer agents.

\section{Acknowledgements}

We express sincere thanks to the Dr. SN Thore, Principal, Deogiri College, Aurangabad for providing the necessary research facilities.

\section{Conflicts of Interest}

The authors confirm that this article content has no conflict of interest.

\section{References}

1 Sundberg RJ, Martin RB (1974) Interaction of histidine and other imidazole derivatives with transition metal ions in chemical and biological systems. Chem Rev 74: 471-517.

2 Wiglenda T, Ott I, Kircher B, Schumacher P, Schuster D, et al. (2005) Synthesis and Pharmacological Evaluation of $1 \mathrm{H}$-Imidazoles as Ligands for the Estrogen Receptor and Cytotoxic Inhibitors of the Cyclooxygenase. J Med Chem 48: 6516-6521.

3 Dahiya R (2008) Synthesis, characterization and antimicrobial studies on some newer imidazole analogs. Sci Pharm 76: 217-239.

4 Hazelton JC, Iddon B, Redhouse AD, Suschitzky H, Woolley LH (1995) $2 \mathrm{H}$-Benzimidazoles (Isobenzimidazoles). Synthesis of Poly substituted O-Phenylenedi- amines and their Conversion into Heterocycles, Particularly 2-Substituted Benzimidazoles with known or Potential Anthelmintic Activity. Tetrahedron 51: 10771-10794.

5 Wolkenberg SE, Wisnoski DD, Leister WH, Wang Y, Zhao Z, et al. (2004) Efficient Synthesis of Imidazoles from Aldehydes and 1,2-Diketones using Microwave Irradiation. Org Lett 6: 1453-1456.
6 Roongpisuthipong A, Chalermchockcharoenkit A, Sirimai K, Wanitpongpan P, Jaishuen A, et al. (2010) Safety and efficacy of a new imidazole fungicide, Sertaconazole, in the treatment of fungal vulvovaginitis: A comparative study using Fluconazole and Clotrimazole. Asian Biomed 4: 443-448.

7 Lombardino JG, Wiseman EH (1974) Preparation and antiinflammatory activity of some nonacidic trisubstituted imidazoles. J Med Chem 17: 1182.

8 Phillips AP, White HL, Rosen S (1983) Antithrombotic triphenylimidazoles. Eur Pat Appl EP 58890, 1982. Chem Abstr 98: $53894 z$.

9 Lee JC, Laydon JT, McDonnell PC, Gallagher TT, Kumar S, et al. (1994) A protein kinase involved in the regulation of inflammatory cytokine biosynthesis. Nature 372: 739-746.

10 Li HS, Rampersaud AA, Zimmerman K (1993) Synthesis and Invitro Evaluation of Rboxyl)-1-Cycloalken-1Yl]-Phenyl]Methyl]-Imidazoles as Nonpeptide Angiotensin-II Receptor Antagonists. J Chin Chem Soc 40: 273-282.

11 Dake SA, Khedkar MB, Irmale GS, Ukalgaonkar SJ, Thorat VV, et al. (2012) Sulfated Tin Oxide: A Reusable and Highly Efficient Heterogeneous Catalyst for the Synthesis of 2, 4, 5-Triaryl-1Himidazole Derivatives. Synthetic Communications 42: 1509-1520.

12 Dake SA, Shinde SV, Vyawahare SK, Marathe RP, Navale RB, et al. (2012) Bioactive Heterocycles: Synthesis and Biological Evaluation. In: Ameta KL, Pawar RP, Domb AJ, (eds.), Nova Science Publishers Inc., New York, USA, pp: 69-95.

13 Nalage SV, Kalyankar MB, Patil VS, Bhosale SV, Deshmukh SU, et al. (2010) An efficient noncatalytic protocol for the synthesis of trisubstituted imidazole in polyethylene glycol using microwaves. The Open Catalysis Journal 3: 58-61.

14 Parveen AM, Ahmed RS, Shaikh KA, Deshmukh SP, Pawar RP (2007) Efficient synthesis of 2,4,5-triaryl substituted imidazoles under solvent free conditions at room temperature. Arkivoc 15: 12-18.

15 Pathan MY, Paike VV, Pachmase PR, More SP, Ardhapure SS, et al. (2006) Microwave-assisted facile synthesis of 2-substituted-2imidazolines. Arkivoc 15: 205-210.

16 Shelke KF, Sapkal SB, Sonar SS, Madje BR, Shingate BB, et al. (2009) An Efficient Synthesis of 2,4,5-Triaryl-1H-Imidazole Derivatives Catalyzed by Boric Acid in Aqueous Media Under UltrasoundIrradiation. Bull Korean Chem Soc 30: 1057-1060.

17 Dake SA, Raut DS, Kharat KR, Mhaske RS, Deshmukh SU, et al. (2011) Ionic liquid promoted synthesis, antibacterial and in vitro antiproliferative activity of novel $\alpha$-aminophosphonate derivatives. Bioorganic \& Medicinal Chemistry Letters 21: 2527-2532.

18 Roham PH, Kharat KR, Mungde P, Jadhav MA, Makhija SJ (2016) Induction of Mitochondria Mediated Apoptosis in Human Breast Cancer Cells (T-47D) by Annona reticulata L. Leaves Methanolic Extracts. Nutrition and Cancer 68: 305-311. 